\title{
A Quantitative Research Study for Determining the Effects of Teachers' Attitude on Students' Learning English Language in Pakistan
}

\author{
Siraj Ahmed Channa \\ Shaheed Benazir Bhutto University Shaheed Benazirabad, Sindh, Pakistan
}

Mansoor Ahmed Channa

Quaid-e-Awam University of Engineering and Technology Nawabshah, Sindh, Pakistan

Rosy Ilyas

Mehran University of Engineering and Technology Jamshoro, Sindh, Pakistan.

Abdul Razzaque Lanjwani

Mehran University of Engineering and Technology Jamshoro, Sindh, Pakistan

Received: July 6, 2020 Accepted: August 29, 2020 Published: September 3, 2020

doi:10.5296/elr.v6i2.17317 URL: https://doi.org/10.5296/elr.v6i2.17317

\begin{abstract}
English learning as a foreign or second language is no more complicated process in modern era. In Pakistan, the young generation is trained with different aspects of life not only in academics but also in professional, social and in psychological domains. This study investigates the effects of teachers' attitude on learning English as a foreign language. The study used survey questionnaire to find the effects of teachers' attitude. Almost 106 participants volunteered for this study from three departments of one university of Pakistan. The gathered data was analyzed through SPSS version 20 to find percentage, mean score and $S D$. The study offered the most promising results based on teachers attitudes on learning English. The results revealed teachers' caring attitude as significant factor related to the cognitive and communicative abilities of the students. Further, the results of this study indicated that the success of the class always depend on teachers' behavior with the most
\end{abstract}


effective impacts on learners' social and academic success. Moreover, this study discusses the detailed information about teachers' attitude on students' language learning, classroom performance and future impact on language teaching and learning.

Keyword: Attitude, English, Academic, Pakistan, Psychological, Foreign language

\section{Introduction}

It is a general fact that the study of English has remained mandatory for all levels of teaching and learning programs at higher institutes of Pakistan. In Pakistan, there is a complex linguistic landscape, around sixty dialects of different languages are being spoken (Rehman, 2002). In addition, the English language is being used throughout the country as an official language. Teaching a foreign language is a prominent profession; it provides countless services to meet the educational needs of an individual. A great teacher possesses caring attitudes that promotes students. Jackson (2012) mentioned that by providing quality of education, teachers can produce quality products. Learning English is the need of time because English is worldwide spoken and written language. Teaching and learning English has become the mass passion and fashion in the present world.

The raise of multilingualism through the advancement of science and technology brought the number of techniques for teaching and learning English. The role of teachers became a moderator and collaborative and equal learner. In the present world of globalization, there is a wide demand for teaching and learning of English. Expanding dominance of the English language at the present world has an effective impact on the research area and concerned people to make something important at the level of competence and performance in the use of the English language.

English is spread in other countries where it is used by the monolingual speakers who are considered to be native speakers of the language. Now, it is spoken around about every corner of the world as a foreign language or second language. In addition, foreign language speaker uses English to interact with the people of other nations. Mollin (2012) stated views on the Kachru's (1985) three-circle model in which he explained that English is no more restricted to native speakers. Further, English is learned as a language of communication with the inner and outer circle speakers of the language. However, the status of the English language is the speaker of the inner circle as a norm-provider, in the outer circle as norm-dependent and in expanding circle, speakers are norm-dependent. The main objective of this research is to investigate the effects of teachers' attitude on students' language learning.

\subsection{The Status of English Language in Pakistan}

The debate of English being a foreign language in norm-norm dependent countries bring modern researcher of the time to this discussion of the status of the English language in Pakistan. A decade before English has normally seen the language of upper-class people. English in Pakistan is associated with the power of elite people who use it as a weapon to maintain their powerful social status. Due to the power and political prestige of the English language to the upper-class people by keeping the distance from ordinary to lower class people. The research view of English is a powerful language in Pakistan as presented by Mansoor and Rasool (2009), by Shameem (2011) and Shah (2002); all of these suggest that the English language has more power as compared to our national and provincial languages; 
because of this language, interference cultural differences are commonly found in Pakistan as a loss of local values and norms.

\subsection{Effects of Teachers' Attitude}

The present study discusses university teacher attitude which is important for the socio-cognitive and academic achievements of the students. Teacher attitude is an action being different at unusual points. It could be positive or negative and effective or ineffective depending upon the condition and situations. Smith (1971) claims that the teachers' attitude can be the most significant factor in teaching and their behavior exercises greater impact on students' learning ability. Throughout the history of social psychology, attitude is considered as the disposition to respond favorably or unfavorably to an object, situation, event or any of the institute. Shah (2002) defined attitude as the mental or neural state of readiness which is organized through experience. Attitude towards the study has a significant contribution to academic achievement and good study patterns.

Teaching up to advance level is more conscious efforts that make learning efficient. Teacher attitudes and students related perceptions are very complex phenomena in day-today interactions where the great teacher

Works for the positive response of students; his actions and decisions always affect the learning outcomes. However, Whitaker's (2019) research study suggests that teachers need to have a strong relationship with the students for building mutual understanding in their relationship. He is of the view that the main variable in the class is not a student, but the teacher and his attitude. Great teachers have high expectations for themselves and for their students. Teachers are the first and most important point of contact in student life. Despite countless characteristics, reforms, resources no other impulse is as profound as the attitude of a man.

\subsection{EFL Teaching Approaches}

English is the main language of instruction for all university courses, where the teacher is supposed to assist students' communication in English effectively. The teacher is an initiator and course designer. He is a role model and counselor of the students who tries to develop students' EFL learning abilities and their activities. A great teacher always remains supportive; he sustains more efforts to modify tastes of his student and engages them more and more in the implementation of modern teaching techniques by taking advantage of all resources. Designing and presenting text is the most complicated center of the teaching process. Every day, a teacher has to plan and make decisions about the instructional process. A teacher's approaches and diverse styles can have a very effective impact on the effectiveness of his or her teaching. However, teaching English language at university level requires diverse approaches to meet the individual learner's needs. It demands socio-cognitive impulses to get better chances of the achievements of the learners.

\section{Literature Review}

The current article focuses on the impact of teachers' attitude which is very important in teaching and learning English as a foreign language. The study on teachers' attitudes as well as students learning English as a foreign language up to the university level is a complex 
phenomenon. The research of Saleh Ahmed (2019) finds that learners with effective attitudes and high motivation perform better than those who were less motivated to learn English as a foreign language (EFL). Teachers' attitude is an important area of concern in the research community of these days. Saleh Ahmed (2019) argued that due to expanding dominancy of English language prerequisite of EFL teaching and learning has forced concerned people or researchers to do something important and urgently to increase all levels of competence and performance of the learners. The area of teacher attitude and motivation has attracted many young researchers to put their efforts related to EFL learning.

According to Rose (2007), the experience of English language teaching, has argued that attachment between teacher and student is the most sensitive relationship in formal and informal education. He stressed that teacher as role models can shape the learner's minds with a specific attitude having different lifestyles and outlooks. He further mentioned that teaching up to the university level is an arrangement and manipulation of the situation where teacher ties to meet the needs of the individual learners. EFL teaching and learning in the nonnative countries is the most committed job because teachers are well qualified; they are mature and trained in all of the language skills; and they have intimated contact to a less mature one.

According to Carr (2004), teaching and learning is prophetic passion in education and teachers' duty is to accept social, moral and uprightness by avoiding from immoral relations including gambling, sexual harassment, abhorring, drunkenness and other excesses. Saussure (1916) stated that language is the need of interaction between community organizations or the same with social institutions, such as inheritance and marriages through the dimension of the language.

Hashwani (2008) states that the attitude of a teacher and student is important to focus when some need to expect positive and effective outcome in the teaching and learning process. The engagement of the students in class room with full concentration can focus on the aim of the class planning to improve their learning interest. Buttner (2014) mentioned that the evaluation of a teacher's attitude or behavior through self-reported level can measure the teacher's self-enrolment in the process of reporting the class room. The study evaluated the two important factors of the teacher behavior including teacher performance and competency. However, Asghar (2016) stated that teacher's self-examination can be undertaken to measure the social, psychological and emotional involvement of his learning and teaching process to develop students' abilities in EFL.

\section{Research Methodology}

\subsection{Instrument and Sampling}

For this study, quantitative research approach was applied. Questionnaire was used as an instrument for this study. Questionnaire was developed by the researcher under the guidance of supervisor to collect data from the respondents of one university in Pakistan. The developed questionnaire was sent to the co-supervisor for checking its authenticity and validity. Both the supervisor and co-supervisor recommended few suggestions which were incorporated and was used for the collection of data. However, the process of data collection was done in three weeks from the undergraduate students of three departments. The department of information technology, department of business administration, and 
department of English were randomly selected for this study. Before collecting data, the permission was taken from the concerned authorities. Every day one hour was given to each department for students to fill the questionnaire.

\subsection{Sampling}

In this study, simple random sampling was used on the undergraduate students from three departments at Shaheed Benazir Bhutto University, Shaheed Benazir Abad. Estimated numbers of Participants were 106 and age between 18 to 28 years old. Simple random technique is used to select the sampling from the population.

\subsection{Data Analysis}

The gathered data was analyzed through SPSS version 20 and simple processes were taken by means of descriptive analysis including frequency, pie diagram and percentage for the perceptions of the students about the teachers' attitude on the students' learning in English at Shaheed Benazir Bhutto University. Moreover, this study was analyzed to measure the perceptions of the students about the teacher attitude and his/ her impact on the students' cognitive and communicative learning in English language and performance of the students in class.

\section{Finding and Discussion}

This research investigates the impact of teachers' attitudes on students learning English as a foreign language. Teaching is the conscious behavior of a person it demands more intellectual efforts to obtain successful results. Language of the human is the most distinguishing characteristic that makes them apart from other creatures. Saussure (1916) stated that language is one of the community organizations and the same with social institutions. However, the studies of language attitudes indicate both the social and cognitive characteristics of the speakers of the language, depending on the particular speaker's accent, speech patterns, vocabulary and communication.

\subsection{Demographic Information of Students}

\begin{tabular}{llllllll}
\hline & IT 18 & $\begin{array}{l}\text { BBA } \\
\mathbf{1 8}\end{array}$ & $\begin{array}{l}\text { English } \\
\mathbf{1 7}\end{array}$ & $\begin{array}{l}\text { Total } \\
\text { Over } \\
\text { age }\end{array}$ & all University & $\begin{array}{l}\text { Grand } \\
\text { Total }\end{array}$ \\
\hline Frequency Male & 25 & 28 & 19 & 72 & & & \\
\% Male & $83.3 \%$ & $75.7 \%$ & $48.7 \%$ & $67.9 \%$ & i). 17-20: 41 & \\
$\begin{array}{l}\text { Frequency } \\
\text { Female }\end{array}$ & 5 & 9 & 20 & 34 & & & \\
\% Female & $16.7 \%$ & $24.3 \%$ & $51.3 \%$ & $32.1 \%$ & & \\
Total Frequency & 30 & 37 & 39 & 106 & iii.) & 24-25: & \\
Total \% & $100 \%$ & $100 \%$ & $100 \%$ & $100 \%$ & 14 & \\
\hline
\end{tabular}

There were 106 participants in this study from three departments of one university in Pakistan. These departments included IT, BBA and English. There were thirty participants including 25 


\section{Macrothink

male students and 5 female students from IT; almost 37 participants from BBA department including 28 male participants and 9 female participants took part in data collection; and similarly, almost 39 participants from English department took part in data gathering including 19 male participants and 20 female participants. There ages range from 20 year to 25 years.

\subsection{Teachers' Attitude Impact on Students' Learning EFL}

Teacher language attitude possesses both cognitive and emotional impulses. According to Fozia (1994), teachers' attitudes are important for educational psychology to develop better cognitive approach of the learners. The teachers' attitude can develop students' social constructivism by the way an individual thinks about the process of social information and formation through language. This is all distinguished learning process comes from university class, where teacher is social constructivist of the minds. The teacher can develop positive expectations and motivations by giving them a sound classroom climate, giving them equal opportunities in class performance, and more positive feedback.

4.2.1 Teachers' attitude impact on students' EFL learning

\begin{tabular}{|c|c|c|c|c|c|}
\hline & & Frequency & Percent & Valid Percent & Cumulative Percent \\
\hline \multirow[t]{6}{*}{ Valid } & Agree & 43 & 42.5 & 42.5 & 42.5 \\
\hline & Strongly Agree & 28 & 28.3 & 28.3 & 70.8 \\
\hline & Not Know & 4 & 3.8 & 3.8 & 74.5 \\
\hline & Disagree & 13 & 13.2 & 13.2 & 87.7 \\
\hline & Strongly Disagree & 12 & 12.3 & 12.3 & 100.0 \\
\hline & Total & 106 & 100.0 & 100.0 & \\
\hline
\end{tabular}

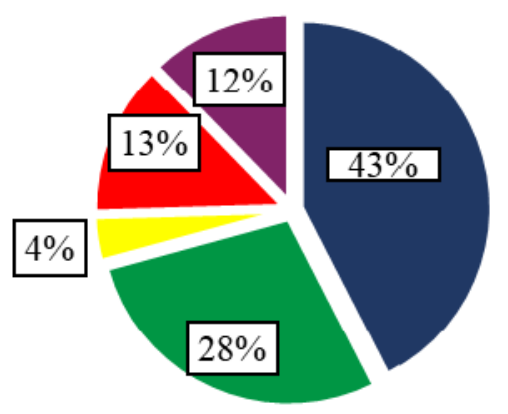

- Agree

Strongle Agree

Not Know

- Disagree

- Strongle Disagree

\subsection{Students Nervousness During EFL Class}

The study shows how students become nervous during English language classes. The study affirms that majority of the student in foreign language classes feel language anxiety in communicative classes. The teacher is only person who can reduce anxiety of the students, and motivate them more in learning process. 
4.3.1 Students Nervousness During the EFL Class

\begin{tabular}{llllll}
\hline & & Frequency & Percent & Valid Percent & Cumulative Percent \\
\hline Valid & Agree & 76 & 75.5 & 75.5 & 75.5 \\
& Strongly Agree & 19 & 18.9 & 18.9 & 94.3 \\
& Not Know & 1 & .9 & .9 & 95.3 \\
Disagree & 5 & 4.7 & 4.7 & 100.0 \\
Total & 106 & 100.0 & 100.0 & \\
\hline
\end{tabular}

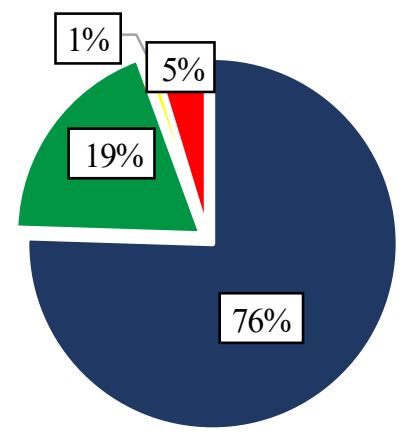

- Agree

- Strongle Agree

Not Know

- Disagree

Results show that how students become nervious during EFL classes. This research study states that students at remote areas of Pakistan are facing so many problems at this modern time, due to unavalibility of scientific and teachincal resources. Teachers are with their continous efforts, motivational attitudes improving the positive results at the English language classes. The study confirms that $76 \%$ respondents were agrees that the feel shy or nervious in EFL classes when ask question to present any kind of presentation; while other $19 \%$ strongly agree on this situation, while five percent students disgree with this statement and percent students can't give their oppion to this statement. The overall result shows that almost 94\% students feel nervous at the time of questioning in EFL class. Teachers' attittude on students' learning in foreign language learning presented that most of the students are facing the problem language anxities. The results show students in question anwer sesssion remain silent they feel shy and fear in in class communication. Teachers' at EFL classes must focuss on speaking anxities of the students, so that they feel it easy and volunterily perform different task and activities.

\subsection{Impact of Teachers' Attitude on Students 'Self-Esteem Learning Development}

The study of Talib (2017) mentioned that self-esteem is a good opinion, self-importance, and conception of oneself. It plays significant importance in laying a solid foundation for student's development. The concept of self-esteem can be expressed as to how we feel ourselves? How do we see ourselves? How we value ourselves? How we adjust ourselves? Learning at the advance level requires students to develop their positive attitude towards self, which is positive self-esteem. Pajares and Miller's (1994) study discussed that self-efficacy belief has a stronger impact on behavior and performance than self-esteem. 


\section{Macrothink Institute ${ }^{\text {TM }}$}

Sumaya (2019) indicated that the effectiveness of learner-centered teaching towards EFL is modifying students' attitude in self-esteem, and motivations in learning. The study showed that learner center teaching brings supportiveness, and cooperation between students by dividing them into groups during the class activities, which gives them a better chance to share their desires and expectations, interpretations, and at the finishing activity of the class, they discuss their different experience and procedures. Learning within cooperative groups intentionally can develop the whole personality of the learners, cognitively, emotionally, and socially. Catherine's (1998) study of cooperative centered teaching concluded that cooperative teaching lead students to develop self-esteem, perceptions, feelings, and academic achievements. Moreover, the study of (McCurdy 1996) showed a significant effect of cooperative learning and teaching on students' academics and self-motivation in classroom activities and educational assignments.

4.4.1 Impact of Teachers' Attitude on Students' Interest, Attention, and Self-esteem Development

\begin{tabular}{lllll}
\hline & Frequency & Percent & Valid Percent & Cumulative Percent \\
\hline Agree & 47 & 47.2 & 47.2 & 47.2 \\
Strongly Agree & 33 & 33.0 & 33.0 & 80.2 \\
Not Know & 11 & 11.3 & 11.3 & 91.5 \\
Disagree & 6 & 5.7 & 5.7 & 97.2 \\
Strongly Disagree & 3 & 2.8 & 2.8 & 100.0 \\
Total & 106 & 100.0 & 100.0 & \\
\hline
\end{tabular}

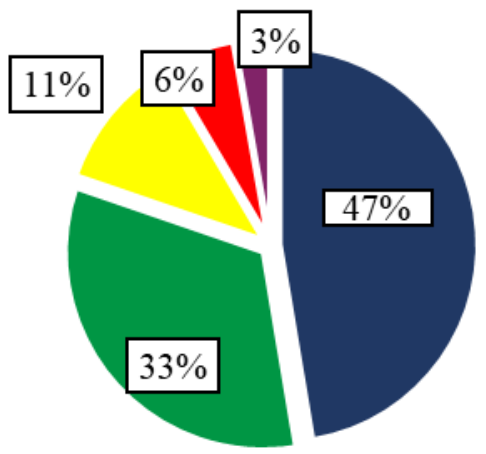

- Agree

- Strongle Agree

Not Know

- Disagree

- Strongle Disagree

\subsection{Impact of Teachers' Attitude on Students' Communicative Learning}

From the previous research studies, this is found that there has been the ever-growing need for good communication skills in English; it has created a wide demand for English learning around the world. Due to potential communicative competence, there is a wide range emergence in the research of the modern world that brought advanced approaches and well-formed communicative language pedagogies as in Sahil M. Asassfeh and Sabri Alshboul (2012). Jack C. Richards' (2006) research study on communicative language learning present 


\section{Macrothink}

that millions of the world language learners struggling to improve English language communicative abilities, they ensure their children to achieve a good command of English. English Language learning is viewed as a vehicle for class communication; it connects students with their teachers, for improving the communicative environment in class.

4.5.1 Teachers; Attitude /Motivation on Students Communicative Learning

\begin{tabular}{|c|c|c|c|c|c|}
\hline & & Frequency & Percent & Valid Percent & Cumulative Percent \\
\hline \multirow[t]{6}{*}{ Valid } & Agree & 33 & 33.3 & 33.3 & 33.3 \\
\hline & Strongly Agree & 49 & 49.5 & 49.5 & 82.9 \\
\hline & Not Know & 6 & 5.7 & 5.7 & 88.6 \\
\hline & Disagree & 6 & 5.7 & 5.7 & 94.3 \\
\hline & $\begin{array}{l}\text { Strongly } \\
\text { Disagree }\end{array}$ & 6 & 5.7 & 5.7 & 100.0 \\
\hline & Total & 105 & 100.0 & 100.0 & \\
\hline
\end{tabular}

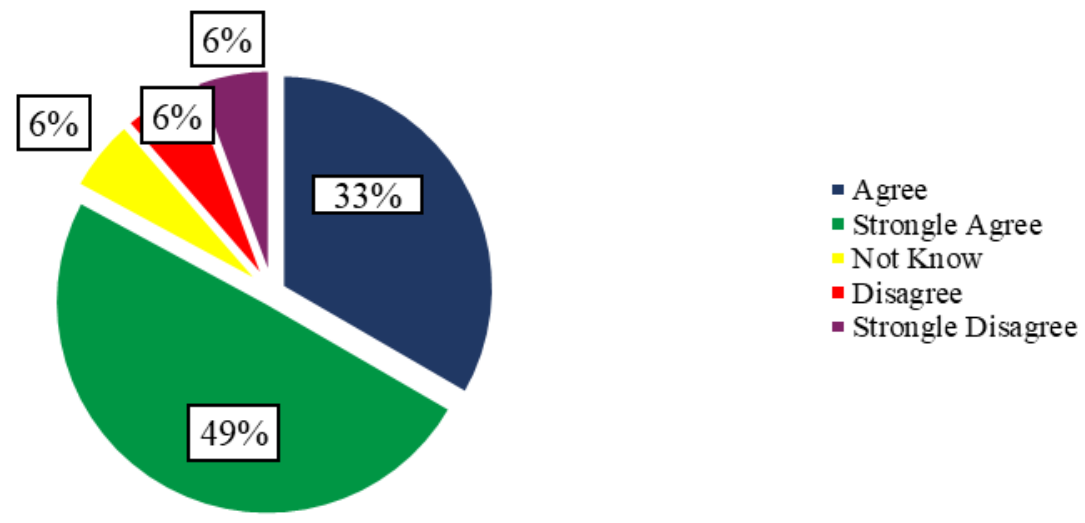

Teachers who communicate effectively in class can give students appropriate and helpful feedback. Great teachers focus on what learner actually needs to be good speaker, teacher, and student interaction is extremely important for successful class; it develops practical side of the student through the entire university and out of university life. Modern American and British linguists introduce many new approaches for the learners provided communicative abilities, new software, apps such Google classroom, digital dictionaries grammar-translation methods, and audio- video lingual methods were produced, English teaching and learning became the dominant language learning and teaching approach in the present world. Language learning is based on three principles as communication principles, task-based principles and meaningfulness principles, these all principles are equally important in the communicative language learning environment (Littlewoods, 1981).

According to Farooq (2001), language learning in term of socio-cognitive aspect it develops social construct, based on communication skills among the learners of the language, more they participate in EFL language activities, more they develop their better understanding. In addition, Anwar (2017) mentioned that the friendly and leadership behavior of the teachers 
can improve the communicative interest of students and give them better results in their learning process. The partnership of the teacher with students should be like a friend or motivator which can give a positive outcome. The implementation of testing methods for student's professional and interpersonal skills in classroom may also give comprehensive access to the student's status of learning and engagement in the learning process.

\subsection{Teachers Appreciate Students When They Perform Well in Classroom}

The student's class performance and academic achievements are always different at different levels of learning, it could be high or low, successful or failure achievement. Successful class performance of the students is mostly found as a result of effective teaching skills, appreciation, and a positive attitude. The present study explores the teacher improved attitude to encourage student strength and try to motivate students in the learning process. The study of Sarwar (2010) explained that high academic achievement has regular class study habits. His study further explores that teacher's expectations towards any students can have a wonderful effect on how students think about themselves and how they perform better academically.

4.6.1 Teachers Appreciate Students With Positive Words When They Perform Well in Class

\begin{tabular}{|c|c|c|c|c|c|}
\hline & & Frequency & Percent & Valid Percent & Cumulative Percent \\
\hline \multirow[t]{6}{*}{ Valid } & Agree & 54 & 53.8 & 53.8 & 53.8 \\
\hline & Strongly Agree & 38 & 38.7 & 38.7 & 92.5 \\
\hline & Not Know & 3 & 2.8 & 2.8 & 95.3 \\
\hline & Disagree & 3 & 2.8 & 2.8 & 98.1 \\
\hline & Strongly Disagree & 2 & 1.9 & 1.9 & 100.0 \\
\hline & Total & 106 & 100.0 & 100.0 & \\
\hline
\end{tabular}

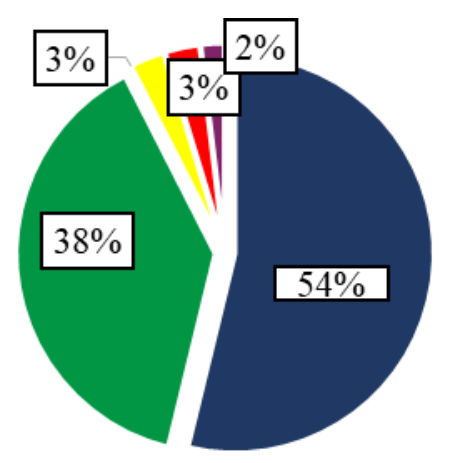

- Agree

- Strongle Agree

Not Know

- Disagree

- Strongle Disagree

The results revealed that the extent of university students' engagement in academic tasks, and activities based on performance can develop their abilities. Students' engagement refers to meaningful engagement to the learning environment. The term explores different meanings and activities of the students; it shows student behavioral engagement, level of interest, cognitive-emotional engagement, increase students' social and moral construct towards the learning process. The results indicated that teachers' affection, care, proper guidance, close 
intimacy is always been there when they perform competently in the class. More over students' behavior provides a glimpse of how the instruction and academic practices are going on in university. Coates (2008) said that institutions like universities and colleges need to provide students with appropriate resources and opportunities as book library and labs with its net access having sufficient space for the students to work collaboratively. Further, institutes must provide play grounds, clean and sound learning environment to the young learners.

\section{Conclusion}

This article concludes that positive teacher attitudes enhance learner's interest in English language learning. Teachers must demonstrate their affection, capacity, motivations, and supportiveness at every step to learners. Again Students are also responsible to participate at every given task, assignments. University class plays an important role and this is only possible object where learners are equally treated with respect and honor in the classroom. Teacher's behavior leaves a deep impact on learner's attitudes towards learning. Moreover, learning is a collaborative process where teachers' attitudes and students' positive perceptions are important factors for output based learning. The study found that teacher's interactive communicative skills in English classes creates a positive image of the teacher in the learner's mind. Thus it develops student's future expectations, like jobs and professional skills. Successful class performance of the students is mostly found as a result of effective teaching methods and positive attitude. Moreover, self-esteem, communicative and class performance depend upon the teacher's attitude, grip on the English language and interaction with students. Thus, a positive attitude brings positive results and negative attitude brings negative response of students.

\section{References}

Ahmad, A., \& Sahak, R. (2009). Teacher- Student attachment and teachers' attitude towards work.

Ahmad, S. (2005). A Study on Motivation of the EFL Learners at Higher Secondary Level in Bangladesh. (pp. 1-55).

Ahmed, S. A., \& Dakhiel, M. A. (2019). Effectiveness of Learner-Centered Teaching in Modifying Attitude towards EFL and Developing Academic Self-Motivation among the 12th Grade Students. English Language Teaching, 12(4), 139-148. https://doi.org/10.5539/elt. v12n4p139

Ansar, A., Rizvi, R. M., Hussain, A., Nawaz, A., Zafar, A., \& Fayyaz, A. (2019). Self and Peer Assessment of Teachers' Attitude towards Teaching. Medical Education, 29(4), 365-370. https://doi.org/10.29271/jcpsp.2019.04.365

Anwar. (2017). Assessing organizational citizenship behavior through constructing emotional intelligence. Asia pacific journal Business Administration. https://doi.org/10.1108/APJBA05-2016-0049

Asassfeh, S. M. (2012). Communicative Language Teaching in an EFL Context: Learners' Attitudes and Perceived Implementation. Journal of Language Teaching and Research, 3(3), 
525-535. https://doi.org/10.4304/jltr.3.3.525-535

Asghar, H. M (2016). Technology use, self-directed learning, student engagement and academic performance: Examining the interrelations. Computers in Human Behavior journal

Büttner (2014). Personality traits of expert teachers of students with behavioral problems: A review and classification of the literature.

Catherine (1998). Assessing distance learners' satisfaction with instruction. The American journal of distance edification, 12(3). https://doi.org/10.1080/08923649809527002

Farooq. (2015). Creating communicative language teaching environment for improving student communicative competence at EFL/ EAP univeritity level. International Education Studies, 8(4). https://doi.org/10.5539/ies.v8n4p179

Fozia. (1994). What are we learning? A case of teacher learning in South African School post.

Geoff, S., Hamish, C., \& Michelle, A. (2008). Learning leaders in time of change. University of Western Sydney and Australian Council for Educational Research.

Hashwani, M. S. (2008). Students' attitudes, motivation and anxiety towards English language learning.

Jackson, D. (2012). Software Abstractions: logic, language, and analysis. MIT press.

Kachru, B. B., \& Nelson, C. L. (1996). World Englishes. Sociolinguistics and language teaching, 11, 71-102. https://doi.org/10.1017/CBO9780511551185.006

Mansoor. (2009). Pakistani postgraduate students' orientations for learning English as a second language: A factor analytic study. System, 51, 77-87. https://doi.org/10.1016/j.system. 2015.04.013

Mansoor. (2009). Punjabi, Urdu, English in Pakistan: A Sociolinguistic Study. Vanguard.

Mathew, J. C. (2004). A frame work for teaching learning English: the dynamics of disposition.

McCurdy (1996). Influence of a cooperative early field experience on preservice elementary teachers' science self-efficacy. Science Teacher Education, 80(4). https://doi.org/10.1002/ (SICI)1098-237X(199607)80:4\%3C419::AID-SCE3\%3E3.0.CO;2-G

Mollin, S. (2012). English in Germany and the European Context. English in the German-speaking World, 31. https://doi.org/10.1017/9781108768924.003

Pajares \& David, M. (1994). Role of Self-Efficacy and Self-Concept Beliefs in Mathematical Problem Solving: A Path Analysis. Journal of Educational Psychology, 86(2), 193-203. https://doi.org/10.1037/0022-0663.86.2.193

Rahimi, M., \& Hosseini, F. (2015). Language Teaching Research The role of teachers' classroom discipline in their teaching effectiveness and students' language learning motivation and achievement: A path method. 


\section{Macrothink}

Education and Linguistics Research

ISSN 2377-1356 2020, Vol. 6, No. 2

Rahman, T. (2002). Passports to privilege: The English-medium schools in Pakistan. Peace and Democracy in South Asia, 1(1), 24-44.

Rahman, T. (2004, January). Language policy and localization in Pakistan: Proposal for a paradigmatic shift. In SCALLA Conference on Computational Linguistics (Vol. 99, p. 100).

Rasool. (2019). Undergraduate students' motivation to learn and attitudes towards English in multilingual Pakistan: A look at shifts in English as a world language. https://doi.org/ 10.1016/j.system.2019.02.015

Richards, J. C. (2006). Communicative Language Teaching Today. Evidence from Panel Data. American Economic Review, 94(2), 247-52.

\section{Copyright Disclaimer}

Copyright reserved by the author(s).

This article is an open-access article distributed under the terms and conditions of the Creative Commons Attribution license (http://creativecommons.org/licenses/by/4.0/). 